\title{
Death, Biography, and the Mapuche Person
}

\section{Magnus Course}

London School of Economics, UK

ABSTRACT The amulpüllün biographical oratory which takes place at Mapuche funerals in southern Chile is said to 'complete' the person. Such a perspective challenges the assumption that mortuary practices necessarily constitute a form of analysis, a division of the component parts of the social person. In this paper l explore what it is about the Mapuche person which needs to be 'completed,' and how funeral oratory achieves this goal. Utilizing Bakhtin's concepts of consummation and transgredience, and Ricoeur's concepts of emplotment and narrative identity, I suggest that it is only from the position of outsidedness that the necessary totalization of the deceased's person can occur. These processes of synthesis and totalization cast light upon an apparent contradiction between the importance which Amerindians place upon biography as an oral form, and theoretical approaches which stress the instability and divisibility of an Amerindian personhood predicated upon the incorporation of the other. Rather than viewing the totalization which occurs in biography as a critique of such an approach, I see it as a solution to the ontological problem which such an approach describes.

KEYWORDs Personhood, biography, funerals, Mapuche, narrative

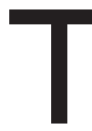

his paper concerns itself with the idea that death and its accompanying social practices reveal something to us about the indigenous conception of the person. Such an idea is closely related to the widely-held assumption that mortuary practices constitute a form of ready-made analysis: 'analysis' as defined by the Oxford English Dictionary as 'the breaking up of anything complex into its various simple elements, the opposite of synthesis' (r989). According to this view, what mortuary practices do is to undo the complex social ties which once held the living person together, and to thereby make visible and explicit the parts of which that person was composed.

ETHNOS, VOL. 72:I, MARCH 2007 (PP. 77-IOI)

(C) Routledge Journals, Taylor and Francis, on behalf of the Museum of Ethnography ISSN OOI4-I844 PRINT/ISSN I469-588X ONLINE. DOI: IO.IO80/OOI4I84070I2I 9544 
This process has variously been described as 'de-conception' (Mosko I983), 'disintegration' (Bloch I988), and 'division' (Strathern I988).

Nowhere in the anthropological literature is this equation of eschatology with the analysis of the person more refined than in the ethnography of Melanesian societies. Perhaps this is why Melanesianists have focused so heavily on funerals - the work of analysis would seem to have already been done for them (cf. Damon \& Wagner 1989). By simply tracing the various exchanges and practices surrounding a death, the social relations of which the person is composed are revealed. Never is the 'dividual' quality of the Melanesian person more in evidence than at death (Strathern I988). Unilineal descent groups seek to purge from their midst the affinal relations into which the deceased necessarily had to engage while alive in order to create new life and maintain the lineage. The focus of this purging may be either the kin of the 'affinal' parent of the deceased, or the affinal relations entered into by the deceased upon marriage. This process of lineage purification occurs in both patrilineal and matrilineal societies. Thus among the patrilineal Bush Mekeo mortuary exchanges are directed towards paying off, and thereby excluding, the deceased's matrilateral kin (Mosko I983). Among the matrilineal residents of Tubetube, mortuary exchanges and taboos serve to extract the deceased's widow or widower from their midst (Macintyre I989). Even in cognatic societies such as the Garia, death rituals are primarily concerned with undoing the relations which constituted the person (Strathern I992).

This view of mortuary practice as breaking down the person is not confined to Melanesia. Indeed, the notion that death necessarily constitutes a process of internal separation would seem to be present throughout the world, a point most famously made by Robert Hertz in his classic paper 'A Contribution to the Study of the Collective Representation of Death' (1960 [1907]). Yet, we must be careful to distinguish between the separation of physiological or pseudo-physiological parts of the individual and the separation of the social relationships of which the social person was composed. ${ }^{\mathrm{I}}$ Thus, although there may always be some degree of separation of parts at death, the nature of this separation may not always be analogous cross-culturally. The separation of the physical body from the consciousness in Western eschatology, for example, is of a fundamentally different nature to the separation of maternal and paternal relations among the Mekeo. Thus, what mortuary practices set out to do clearly depends upon the relevant conception of the person. Yet, it is clear that whether or not one is referring to the physical individual or the social person, death and its accompanying social practices 
are commonly perceived as processes of the division and separation of parts.

In the ethnography of Native South America, approaches to death such as those by Carneiro da Cunha (1978), Overing (r993), Perrin (1987), and Viveiros de Castro (I992), have focused primarily on death as a category of cosmological speculation rather than as a revelation of the nature of the Amerindian person. ${ }^{2}$ However, in recent years more and more attention has been directed toward the role of ritual practice in revealing the component aspects of the person. Much of this work has been heavily influenced by Melanesian studies. Indeed, José Kelly has imported Wagner's concept of the 'fractal' person (200I), while in other recent work both Eduardo Viveiros de Castro and Suzanne Oakdale speak of Amerindians as 'dividuals' (Viveiros de Castro 2002; Oakdale 2005). Yet, the importation of Melanesian models of society to the Americas may actually obfuscate more than it clarifies. ${ }^{3}$ The dividual quality of the Amerindian person may well be of a different nature to that described in Melanesia. There is something of a slippage in equating the separation of a 'consanguineal' body from an 'affinal' soul in South America, with the separation of, say, 'consanguineal' maternal from 'affinal' paternal substance and relations in Melanesia. Whereas in the former case, what we could call 'consanguinity' and 'affinity' refer to generalized symbolic values, in the latter they refer directly to bounded aggregates of people. Nevertheless, it is the possibility of division and separation implied in a reliance on the incorporation of the other which comes to the fore. This divisibility and subsequent instability are increasingly presented as the defining traits of Amerindian personhood, a personhood described by Anne-Christine Taylor as 'chronically unstable and forever partible' (I998:318).

Now this process of division and separation is also clearly in evidence in the funerals held by the Mapuche of southern Chile. ${ }^{4}$ The body becomes separated from the alwe 'living essence,' the am 'soul,' and the püllü 'spirit;' before all of these separated parts move on to an unspecified and unknown destiny. ${ }^{5}$ Yet, a more subtle approach reveals a counter-current, a process through which, rather than disintegrating or deconceiving the social person, the component parts of the person are actually brought together. My focus in this paper is therefore not on death as a process of analysis, but rather on death as process of synthesis. In particular, I shall elaborate on that part of Mapuche mortuary practice referred to as amulpüllïn, literally, 'the making go of the spirit.' Mapuche people state explicitly that this form of oratory serves to 'finish' or 'complete' (derwman) the person. This raises two questions: what

ETHNOS, VOL. 72:I, MARCH 2007 (PP. 77-IOI) 
is it about the Mapuche person that needs to be 'finished'?, and secondly, how does amulpüllün funeral oratory achieve this stated goal? In answering these two questions I will return to the twin themes of this paper: the assumption that eschatology equals analysis, and the nature of the Amerindian person, dividual or otherwise.

\section{The Living Person}

Before describing what happens when a Mapuche person dies, I would like to provide a brief outline of the kinds of relations which Mapuche persons both create, and are created by, while alive. Such an outline necessarily entails a discussion of Mapuche 'social structure,' a topic which has been the subject of much debate over the years. For Louis Faron, Mapuche society could be understood as essentially patrilineal (I96I). He argued that confinement upon reservations by the Chilean state at the turn of the twentieth century crystallized a pre-existing patrilineal tendency by curtailing possibilities of migration, and hence the fission and fusion of groups, as well as by creating a legal situation in which a tie of descent to the reservation founder became paramount. Milan Stuchlik, however, saw the implementation of the reservation system as having the opposite effect: the fixity of local groups led to genealogical and spatial proximity taking precedence over lineal ties, thus Mapuche society could be better conceptualized as bilateral or cognatic (I976). Much of this disagreement results from attempting to understand Mapuche society in terms of visible social aggregates which, due to the contingencies of history and geography, are highly heterogeneous and variable. Some of this confusion disappears if we try to understand social aggregates from the perspective of the concept of the person. Marilyn Strathern's comment regarding earlier generations of Melanesian ethnographers is equally applicable to prior studies of Mapuche society: 'Social life was thus conceptualized as the person's participation in a plurality. As a result, an individual person was only ever a part of some more encompassing aggregate' (I992:86).

Central to any understanding of the Mapuche person and the social aggregates to which it gives rise is the concept known in Mapudungun as küpal, a concept translated by Mapuche people into Spanish as descendencia 'descent.' ${ }^{6}$ Each person is the product of the combination of their mother's menstrual blood and their father's semen. Both of these substances transmit both maternal and paternal küpal; semen thus links a child to both paternal grandfather and grandmother, while menstrual blood creates a link to both maternal grandmother and grandfather. Mapuche people thus place great

ETHNOS, VOL. 72:I, MARCH 2007 (PP. 77-IOI) 
importance on their meli folil or 'four roots' - a metaphorical allusion to one's four grandparents. Küpal is understood to be a 'given' component of the person: fixed, immutable, and permanent from the moment of conception. Its influence is visible in each person's physical characteristics, in their relations with spirits, in their capacity to fulfil certain social roles, and in their moral behaviour.

As well as being an essential aspect of the person, küpal can also be understood as the basis of a relation between persons. Thus, someone can be said to 'share' küpal with all of their consanguineal kin. Yet, although at one level küpal suggests a theory of bilateral or cognatic descent, in terms of sharing küpal, the term takes on a distinct patrilineal bias. A virilocal tendency means that men spend most of their lives with those with whom they share küpal, whereas married women tend to be separated, both socially and spatially, from such people. Thus the bilateral concept of küpal becomes a patrilineal concept when its meaning is extended from a component of personhood to the level of the inter-personal relations. This co-residence of men, unmarried women, and children who share küpal leads to the idea of being of kiñe küpal, of 'one descent.' Relations between those patrilineally-related co-residents who share küpal are predicated on a notion of similarity and identity which leads to an ethic of obligatory mutual assistance and solidarity. Yet, such relations are also often fraught with problems, particularly as such relations often hinge on attempts to assert authority between and within different generations, attempts which challenge the fundamental autonomy of the Mapuche person.

Matrilateral relations are referred to as küpal ñuke püle, literally 'descent by the mother.' These relations are characterized by perceived difference and supposed equality. People enter into exchange relationships with their matrilateral kin, whereas they very rarely exchange with their patrilineal kin. Relationships created through marriage often closely resemble those with matrilateral kin. Indeed, matrilateral cross-cousin marriage (ñukentun) was previously an idealized and preferred form of marriage. The concept of küpal thus refers to many things - both to an essential aspect of the person and to the form of certain relations, to both patrilineal relations and cognatic relations. It is perhaps the polysemic quality of this central aspect of the Mapuche person which has led to confusion amongst ethnographers who have sought to understand the person through the social aggregates of which they are members.

Relations of identity between people of kiñe küpal are a key factor in the composition of 'groups' such as comunidades and lof. The Spanish term

ETHNOS, VOL. 72:I, MARCH 2007 (PP. 77-IOI) 
comunidad refers in the Mapuche context to a legally-constituted group of people resident on one reservation, the Mapuche term lof refers to a localized group which may span one or more reservations. ${ }^{7}$ Although in some cases kine küpal, lof, and comunidad are synonymous, in others they are not. We can generalize by saying that comunidad is primarily a jural concept, lof a territorial concept, and kiñe küpal a kinship concept.

Yet, this entire discussion of the Mapuche person and the social aggregates to which aspects of the person give rise omits one crucial fact. ${ }^{8}$ This is that to be a 'true person,' to be che, one must go beyond relations with one's kin, whether these be maternally or paternally-related. While these relations are chronologically preceding, it is those relations which a person creates through their own volition during the course of their life that allow them to be a person. The paradigmatic form of such relations is the exchange of wine between male friends (wenüy). This exchange is ideally reciprocal and occurs at games of palin, a highly ritualized sport resembling field hockey, at ngillatun fertility rituals, at funerals, and in everyday interactions. It is impossible to overestimate the importance of friends as it is through the activation of the capacity to form relationships with unrelated others that one becomes a true person. ${ }^{9}$ This conceptualization of personhood is clearly open-ended and externally-oriented towards others. Indeed, Mapuche personhood could accurately be described as centrifugal, a constant movement outward, both in metaphorical terms of genealogical proximity and the literal meaning of geographical space. This conceptualization of the person resonates with Viveiros de Castro's description of the Araweté as 'beings of becoming' (I992:252).

This outline of the Mapuche person and Mapuche 'social structure' has of necessity been brief and superficial. Nevertheless, I hope that three key points have emerged which will have bearing on the discussion of mortuary practices below. Firstly, and most obviously, the Mapuche person is necessarily predicated on various kinds of others, both kin and non-kin. ${ }^{10}$ Secondly, the person cannot be seen as simply the sum of the maternal and paternal relations from which they were conceived. This is because to become che, to become full persons, one must go beyond these initial relations and enter into progressively more distant social relations. Thirdly, these relations through which the person constitutes itself are diffuse and open-ended. Mapuche personhood can therefore be conceptualized as an ongoing project of selfcreation. 


\section{Overview of Funeral Practices}

Death for Mapuche people is the absence of life (mongen) where it once was present. It is, in this sense, represented as pure negativity, a lacuna registered in its linguistic formulation, lan, the verbalized form of the suffix $l a$, a suffix used to negate any other verb. Death is nearly always considered the result of the volition of others, whether these be witches (kalku), demons (weküfe) or other malevolent forces.

Once a person has died, the corpse is washed, usually by a close female relative, and the deceased is dressed in his or her best clothes. The body is kept within the house and placed on a low platform made from two planks of wood, or on a table. Its hands are crossed over the chest and a hat or headscarf is placed over the face. Small candles are lit and placed around the body, which should always have its head to the east. Previously, the corpse was placed on a similar raised platform known as pillguay, but outside of the house. People are somewhat reluctant to touch the corpse, but it is not said to be in any way polluting or dangerous. There occurs no disposal of the deceased's possessions, and people continue living in the house where the death occurred. The only prohibition related to death practices noted by earlier writers was that on the use of the deceased's name (Latcham 1924:497). To this day Mapuche people tend to avoid mentioning the dead person by name in the presence of the corpse, referring to it in Spanish by the term $e l$ finado meaning 'the late,' or in Mapudungun by using the appropriate kinship term with the added suffix $\mathrm{em}$ meaning 'deceased.' ${ }^{\prime r}$

Any available young men are sent out as werken 'messengers' to inform the deceased's relatives of their loss. Another werken will be sent to inform the headman (lonko) of the lof to which the dead person pertained. This headman will in turn send out his own werken messengers to inform the rest of the lof of the death and to arrange a meeting of male lof members to take place the following day. The meeting will be attended by the men of the lof, and, if the deceased was a woman, some of her natal kin. The purpose of the meeting is primarily to decide whether the deceased will be given a full funeral (eluwiün) or simply a wake (Sp. velorio, Map. umatun) followed by burial. Many lof members are unwilling to hold full funerals for those whom they consider to have contributed little to the activities of the lof. As one man put it to me, 'Why should we participate in their funeral when they never participated in anyone else's?' This reluctance is furthered by the high costs involved: all those who participate in a full funeral must slaughter either a pig or a sheep as well as purchasing large quantities of wine and cider.

ETHNOS, VOL. 72:I, MARCH 2007 (PP. 77-IOI) 
It is normally only children, unmarried women, and single men who have broken off relations with their patri-relatives, for whom solely a wake is held. As well as establishing whether or not a full eluwïn is to take place, the lonko will also try to gain a consensus as to the date for the funeral. This will nearly always be four days after the death in order to keep in accordance with the auspicious nature of the number four. If the family is particularly well-off, or if the person died in mysterious circumstances, the body may be sent to one of the undertakers in the local town, before being returned in time for the wake.

The space of four days between death and burial is a relatively new practice brought about by the exigencies of the Chilean Ministry of Health. Some of my older informants remembered the days when the interval between death and the final funeral was up to three months. The apparent rationale behind the lengthy delay was threefold: firstly, it allowed distant relatives time to arrive and observe the corpse before burial; secondly, it allowed the deceased's lof time to gather all of the necessary provisions for the full eluw ün funeral to take place (in particular, for the mudai corn beer to ferment); and thirdly, it allowed time to carve out the great wampo canoe in which the deceased would eventually be buried. ${ }^{12}$ To prevent premature putrefaction, a fire of damp wood known for its antiseptic qualities was built under the pillguay platform to smoke the corpse. ${ }^{\mathrm{I} 3}$ Despite the drastic reduction in the interval between death and final burial, it is still considered vital that the requisite four days pass before the burial can take place. Even in the days when a full three months interval was allowed, the time between the final meeting of the lof and the eluzwïn itself would still correspond to the auspicious four days.

Visitors start to arrive at the house as soon as the death is known. They bring with them food, mate tea, or cider as gifts to the closest adult male relative of the deceased, known in Spanish as el doliente and in Mapudungun as ngen la or ngen lladkun (literally: 'master/owner of the dead' or 'master/owner of grief'). As well as offering food and alcohol, the visitors also offer their condolences to the deceased's family. These condolences are known by the Spanish term visitas de pésame. The visitors proceed to look at the corpse and frequently raise a toast with either wine or cider, making sure that a few drops fall to the floor before drinking. Those coming from a long distance will be provided food and lodging until the burial, while those coming from close by will stay for a while and then go home. People place a great emphasis on seeing (pen) the corpse and this seems to me to be the primary reason for its display as Mapuche epistemology is predicated primarily on first-hand visual experience. Many stories tell of people who, having not seen that their loved 
ones have died, are tricked by the ghosts of their kin to follow them to the land of the dead. Perhaps as a result of this fear, the deceased must be seen to be dead. The Mapuche display of the dead forces the deceased's relatives to accept his or her change in existential status.

\section{The Wake}

Regardless of whether or not a full funeral is to be held, the night before the burial all of the deceased's friends and relatives gather at the corpse for the wake, known in Mapudungun as umatun and in Spanish as velorio. ${ }^{\mathrm{I}}$ The use of the term velorio is perhaps slightly misleading as the holding of the wake far predates conversion to Christianity. All men who attend bring with them either wine or cider, whereas women usually bring mate tea, bread, and occasionally sugar. These gifts are brought to help the bereaved family pass the night and to share with the deceased one last time. In theory everyone who attends the wake remains in attendance until the morning when the body is taken to a nearby field. In practice, however, many people come for just a few hours before returning home. Mapuche wakes tend to involve heavy drinking, but drinking of a far more controlled and sombre manner than that which occurs at the funeral itself. People drink around the coffin, toasting each other and the deceased, and frequently allowing drops of liquid to fall on to the floor at the coffin's side. This drinking, known in Mapudungun as pütufkülen, is done out of the belief that the soul of the deceased lingers around the coffin until bid farewell in the funeral itself. The stated purpose of the wake is that of accompanying the deceased's family on the final night before the funeral, but many people told me that they are equally there to accompany the deceased itself for one last time. The most significant aspect of the wake is the carrying out of a reduced version of the ritualized funeral oratory known as amulpüllïn literally, 'the making leave of the spirit/soul.' This discourse is carried out four times during the wake: early evening, midnight, early morning, and dawn. A full account of amulpüllïn is contained below in the description of the eluzwïn, the full funeral.

\section{Eluwün}

The morning following the wake, the body is placed in the coffin which has either been assembled out of rough-hewn planks, or purchased from the local undertaker. It is then taken to a reasonably flat, uncultivated field near the house in which the wake was held and placed on a raised wooden frame or, if the deceased's family can afford it, a collapsible metal platform also

ETHNOS, VOL. 72:I, MARCH 2007 (PP. 77-IOI) 
provided by the local undertakers. Most of the coffin's lid is covered with flowers, as well as with any possessions which were of special importance to the deceased. The very end of the coffin, however, is left open so that the face of the deceased remains on view. In some cases, food and a bottle of wine are placed in the coffin to help the deceased on the journey to wherever the souls of the dead go. However, this practice is now rarely carried out, due in part to the Catholic church's frowning upon such behaviour. In addition, a cross is sometimes placed at the head of the coffin. ${ }^{15}$ Around mid-morning, the relatives of the deceased and the families of the lof to which the deceased belonged arrive in ox-carts and start setting up their cooking areas along three edges of the field. In theory all of the deceased's lof will participate, while only the very closest of the deceased's matrilateral relatives will do so. If the deceased was a woman, there will frequently be three different sets of people participating in her funeral: the lof into which she married; her close kin with whom she shared kiñe küpal; and those with whom she was related matrilaterally. The brunt of the weight of providing hospitality falls upon the lof into which she married, as in actual fact her natal kin can be, should they so wish, receivers rather than givers of hospitality. According to my informants, it used to be the case that the host lof were the only people to provide hospitality; everyone else present would be considered a guest. The fact that these days many of the people who would previously have been considered 'invited guests' now provide hospitality as 'hosts' has blurred the dualistic nature of the funeral.

Around lunchtime, people from all of the surrounding areas start to arrive. All of these guests are referred to as koye, which can be translated roughly as 'uninvited guests. ${ }^{16}$ Upon arrival the koye tend to congregate around the outside of the field in which the funeral is taking place. When men of the host lof see a friend or affine among the waiting koye, they approach them and invite them to proceed to eat at their table. Once seated, the koye is given a plate of meat and bread, and usually a bottle of wine. Other members of the host lof may come over to where the koye is seated and each give him a further plate of meat and a further bottle of wine. The koye will usually put the meat into a plastic bag to be taken home to his family. The wine, however, will all be drunk during the funeral. It is not rare to see men with several plastic bags overflowing with chunks of cooked meat, and with more than ten bottles of wine lined up on the table in front of them. As several koye may be seated at each lof member's table, the lof members themselves are occupied in observing keenly which of their friends are seated at other tables. This reflects

ETHNOS, VOL. 72:I, MARCH 2007 (PP. 77-IOI) 
the great importance Mapuche men place upon providing hospitality to all those from who they have received hospitality previously.

If the deceased was a particularly prestigious and well-known person, ritual circuits of the coffin may be carried out at intervals throughout the eluwïn. These sets of four anti-clockwise circuits are known as awun. ${ }^{17}$ Anybody present can participate in the azoun, although it is usually led by people from the deceased person's lof. Many of those in the awun will play traditional instruments such as the trutruka horn trumpet, or the kull-kull bugle. The kültrung shamanic drum is only played if the deceased was a shaman. The stated purpose of the awun is to create a sacred space from which all malevolent spirits drawn to the corpse have been frightened away.

At some point in the proceedings the local Catholic priest will appear in a pick-up truck. The relatives of the deceased attempt to persuade everyone to turn away from drinking and eating to attend as the funeral rites of the Catholic church are carried out over the coffin. Most adult men, however, completely ignore the arrival of the priest and instead remain seated at the tables of their hosts, drinking wine and talking loudly. It is only women, children, and a small handful of the deceased's closest male relatives who attend the Catholic part of the funeral. The priest usually makes the service as short as possible, and after receiving some food from the 'owner of grief,' he departs. It is only once the priest has departed that the aspect of the funeral which my informants identified as mapuche wimtun 'Mapuche custom' or admapu 'the way of the land,' begins.

A short while after the priest has left, a representative of the 'owner of grief,' goes around all of the hosts' tables and asks that everyone, hosts and guests alike, attend the amulpüllïn funeral discourses to be held shortly. Although some of the more resolute drinkers stay at their tables, most adult men and remaining adult women make their way to the crowd now gathering around the coffin, and wait there for the amulpüllïn to begin. As we shall see, this spatial condensation of social relations around the coffin mirrors the verbal condensation of social relations achieved through the discourses themselves. ${ }^{\text {I8 }}$ Amulpuillün is the most essential component of the Mapuche funeral, as it is this which enables the spirit of the deceased to be sent correctly upon its way. ${ }^{19}$ The etymology of amulpülliun makes this clear: amul is the subjunctive form of the verb amun 'to go,' while püllü is the term for 'spirit.' Due to the prohibition on photographic or audio recording of ceremonial discourses, I am unable to provide word-for-word transcriptions of amulpüllïn. My analysis is based upon my memory of the discourses, and upon discussions with the

ETHNOS, VOL. 72:I, MARCH 2007 (PP. 77-IOI) 
orators themselves held at a later date. The amulpüllün always consists of three stages: the pentukun, the greeting between the speakers; the nutramtun, the biography of the deceased; and the mariepull, the toasting of the deceased.

I will return to the amulpüllïn in more detail in the analysis which follows, but here I provide a simple overview of the events. The headman of the host lof, or in some cases the 'owner of grief,' asks two people to come and give the formalized funerary discourse which is sometimes known by the general term for 'oratory,' wewpin, and sometimes by the term nutramtun, translatable as 'history' or 'biography.' The two speakers, referred to as wewpife, 'orators,' face each other across the coffin. The speaker who represents the host lof starts the usual sequence of pentukun which involves a lengthy description of his own family history and achievements interspersed with questions to his counterpart. The counterpart responds with his own description. Once the pentukun is over, the nutramtun biography of the deceased begins. The nutramtun is over when each speaker picks a bottle from those lined up on top of the coffin, takes a long swig, and then hands it across the coffin to his counterpart. These bottles lined up along the coffin are known as the mariepull. The term mariepull would seem to be derived from the numeral mari epu meaning 'twelve.' However, the actual number of bottles lined up usually exceeds twelve, as every lof member and relative participating in the funeral as a host must provide a full bottle of wine, or more usually, cider. Once the two zerwpife have exchanged bottles, people from the surrounding crowd come forward, grab bottles, take a few swigs, and pass the bottle to anyone who happens to be standing close by.

The drinking of the mariepull marks the end of the amulpüllün. Once the amulpüllïn is finished, the body is taken by ox-cart or pick-up truck to the local cemetery. Only some of the people present at the eluwïn follow the body to the cemetery, most stay behind to continue drinking, although by this time the formalized hospitality has somewhat disintegrated as most hosts will have attended to all the guests to whom they needed to reciprocate, and have now themselves set to drinking. The burial itself is a simple affair: the coffin is lowered into the grave, each person present throws in a handful of dirt, and everyone returns home or to the site of the eluwïn, leaving a couple of volunteers to fill in the grave completely.

\section{Amulpüllün as Consummation}

The day after a funeral there are always two main topics of conversation: from whom did each person receive wine and meat; and, how well was the 
amulpüllïn carried out. Whereas the first topic refers to the continuation of sociality among the living, the second refers to the ending of the sociality of the deceased. Here I describe in greater detail the words and actions which comprise the amulpuillïn, as it is this which achieves the stated goal of the funeral: to finish the person and thereby send it on towards its unknown and unspecified destiny. Just as in life the autonomy of the Mapuche person is premised on its relations with others, so too in death it is the task of others to secure this autonomy through the termination of the networks of sociality through which the deceased constituted themselves. Amulpüllïn, then, is the final word in the dialogue of the person's life.

Let us begin our analysis of the amulpüllün by focusing on the identities of the two primary orators, the wewpife or wewpin. People say that, ideally, at the funeral of a man, one of the speakers is a close patrilineal relative of the deceased, someone with whom they shared kiñe küpal. The other speaker should belong to the kiñe küpal of his mother, his matrilateral kin. At the funeral of a woman, one of the speakers should be from her husband's kine küpal, while the other speaker should be from her own natal patri-relatives. When we bear in mind that women become 'as affines' to their own natal kin, we can start to understand that the apparent gender difference of the amulpüllïn is not as incongruous as it first appears (Course 2005). In both male and female cases, one speaker represents 'consanguines' and the other 'affines.' I should point out, however, that in none of the funerals which I witnessed were the wewpife actually close kin of the deceased. The deceased's close kin were usually said to be 'too sad' (lladkun) to perform such a role. ${ }^{20}$ Furthermore, these days there are many instances when there is no one sufficiently skilled from one or both of the relevant kiñe küpal to give such an elaborate discourse. In this case a speaker is selected from the lof of which the relevant kine küpal is part. Failing that, the relevance of kinship ties is subsumed by that of geographical ties as it is stipulated that in the absence of speakers from the relevant lof, the two speakers must come from lof located either side of the deceased's lof. What is important is that the two zveropife be 'different,' a fact made visible by their facing each other across the coffin.

The host werwpife, that of the lof hosting the funeral, starts the discourse with the pentukun, an elaborate mixture of greeting and autobiography. In the pentukun the speakers outline their own relation to their meli folit, the 'four roots' of their küpal, but particular emphasis is given to patrilineal descent and the kiñe küpal to which it gives rise. The discourses take the form of a dialogue, the first speaker outlining an aspect of his descent and then inqui-

ETHNOS, VOL. 72:I, MARCH 2007 (PP. 77-IOI) 
ring of his counterpart the same aspect of his descent. The speakers then go on to comment at length on their own achievements: the places they have been, the places they have worked, the events which they have organized and any Chilean dignitaries they may have met. A frequently-voiced criticism following a funeral is that these days wewpife spend more time on the pentukun than on the nutramtun biography, extolling their own virtues rather than those of the deceased.

Once the pentukun greeting has come to an end, the host werwpife commences the nutramtun, the biography of the deceased. He outlines the aspect of the deceased's küpal which relates to his own position as representative of the deceased's patri-relatives. The speaker representing the deceased's matrilateral kin confines himself to outlining the deceased's matrilateral genealogy. Both speakers take great care in not missing out any relatives they deem to be of significance. In effect, this genealogical aspect of the nutramtun serves to unravel the paternally-derived and maternally-derived elements of the deceased's person through making them explicit (Faron 1963). Such elements, which can be seen as corresponding to consanguinal and affinal elements of the person, are, in a sense, abstracted and generalized to a level beyond that of the person. What is stressed is the place of the deceased in a chain of relations stretching back through time, and therefore in what could be seen as an enduring 'group.' At first glance, then, the nutramtun would seem to echo the funeral rites described for Melanesia and elsewhere which 'disintegrate' the person into the patri- and matri-groups from which they were composed. This disintegration is simply a shift in scale between the congruous units of the 'dividual' and the 'group' (Strathern I988). However, as we shall see, there is far more to the nutramtun than the citing of genealogy - and there is far more to the Mapuche person than the sum of its paternal and maternal parts.

Once the recounting of the genealogy of the deceased is over, the host zeropife starts to recount in great detail what he perceives to be the most salient aspects of the deceased's life. The aspects selected tend to be those arenas of Mapuche life in which the sociality of friendship comes to the fore - the sport of palin, the ngillatun fertility ritual, and funerals - as it was through these that the deceased created themselves in life as a true person, as che. The participation of the deceased in such events tends to be recounted in a generalized fashion as a quality or characteristic of the deceased rather than through reference to specific events. What emerges in these opening stages of the nutramtun tends to be a slightly generic image of the deceased

ETHNOS, VOL. 72:I, MARCH 2007 (PP. 77-IOI) 
as kümeche, literally a 'good person,' a term which above all else implies generosity. In addition to this abstract moral appraisal, the wewpife also comment more specifically on the technical capabilities of the deceased. Thus, men are often characterized as good horsemen, diligent farmers, or most commonly, great palin players. Women, on the other hand, tend to be spoken of as gifted weavers or capable gardeners.

Once the first wewpife has recounted this rather generic portrait of the deceased, the second weropife starts to add details of which the first speaker may have been unaware: an educational qualification, the captaincy of a sports team, a period of military service. This in turn prompts the initial speaker to respond with yet more details of the deceased's life. The alternating dialogue has a competitive edge, and it is this competitive element to the nutramtun which ensures that no stone remains unturned in the biography of the deceased. Implicit in the competition between the wewpife is disagreement over the relative salience of different aspects of the deceased's life. Yet these disagreements are never made explicit or commented on even after the funeral is over. Rather, what is emphasized is the overall effect that such discourses have in completing the person, perhaps an example of what Ricoeur refers to as 'discordant concordance' (I99I:2 I). ${ }^{21}$ 'Just as the person was in life, so we must describe them in death,' proclaimed Roberto, one of the most experienced wewpife in the area, 'If they were a great footballer, we tell of their goals and put their shirt on top of the coffin. If they were a great palife (palin player) we tell of their great games and clash wïño (palin sticks) over the coffin. That's how it must be if the person is to be finished.' Thus every place they visited, every palin and ngillatun in which they participated, every anecdote they told, every friend they made - all must be recounted and made explicit. The positive image of the deceased emphasized in the opening stages of the nutramtun is ultimately tempered by an elaboration of their less appealing qualities as the discourses progress. These negative traits frequently include drunkenness, laziness, and violence and are usually expressed in no uncertain terms as permanent states of being. This is often achieved through the use of the suffix $-f e$, in terms such as mollife 'drunkard,' chofüfe 'lazy person,' or kezwafe 'brawler.' My informants always impressed upon me the necessity of recounting the negative aspects of the deceased's life with just as much care and veracity as the positive if the amulpüllün as a whole were to serve its purpose. Nevertheless, it is true to say that the time spent on recounting the positive aspects of the deceased far outweighs the time spent on the negative.

ETHNOS, VOL. 72:I, MARCH 2007 (PP. 77-IOI) 
Once the two werwpife have exhausted their reminiscences of the deceased, the headman of the host lof, or in some cases the 'owner of grief,' ask the crowd if anybody else wishes to add anything. Friends of the deceased, both men and women, come forward and state briefly anything which they feel the werwpife may have overlooked. Whereas the wewpife tend toward describing the deceased's life in generalized or even generic terms, the friends of the deceased tend to recount specific events in which they had interacted with the deceased. The discourses of friends also differ in that they incorporate memories of the deceased throughout their life, from childhood to death, whereas the wewpife focus primarily on the deceased's adult life. Yet, like the reflections of the wewpife, the accounts of friends tend ultimately to be centred around the sociality of friendship and corresponding acts of exchange and sharing: a gift of wine, a shared journey, shared experiences of military service, or shared migration to Santiago. Accounts of the deceased's childhood are usually centred around experiences shared in school, which is significant as the first place in which the sociality of friendship starts to supersede that of kinship.

The combined effect of the nutramtun is said to be that it 'finishes' or 'completes' (dewman) the person. ${ }^{22}$ This raises the question of what exactly it is about the person that needs to be 'finished' and how this polyphony of voices achieve such an end.

Upon reaching old age, both men and women voice their fears about leaving things 'unfinished' (dewmalay) and 'abandoned' (trangey). Women tend to focus especially on the question of who will care for their garden and who will finish their weaving. Men, on the other hand, tend to worry about who will pay off the debts of hospitality they have accrued as guests at funerals, games of palin, and ngillatun fertility rituals. This sociality of exchange is based upon a notion of reciprocity - indeed it is this mutually obligating reciprocity which keeps relationships of friendship, wenüyzen, perpetuated through time. Death inevitably cuts such reciprocity short, and proves an insurmountable obstacle to the repayment of the inevitable debts every adult has accrued.

Many older people attempt to resolve this dilemma by staying at home and withdrawing from the webs of sociality before death catches up with them. This change in social status is described simply as 'He or she no longer goes out' (tripazvelay). Nevertheless, such attempts can do nothing more than ameliorate the problem. This is because the extent to which the person is predicated on relations with others far surpasses the remembrance of mate- 
rial exchanges of wine and meat. For the person not only leaves 'unfinished' those relationships predicated on the sociality of friendship, but also those relationships given at birth: the relations with those with whom one shared kiñe küpal, and the relations with one's matrilateral kin, not to mention the extension of these modes of sociality through having one's own children.

As I mentioned previously, the Mapuche person is predicated on different kinds of ongoing relationships with others. Death leaves such relations in limbo, and by removing the person from the realm of sociality leaves them in a diffuse and 'unfinished' state. The project of self-creation is brought to an abrupt halt, but still short of its final destination. The responsibility of 'finishing' the deceased necessarily falls to those still alive.

Yet, the question remains of how the amulpüllïn actually achieves this 'completion' of the person, a question I seek to address using the concepts of transgredience and consummation as described by Mikhail Bakhtin in his early essay 'Author and Hero in Aesthetic Activity' (I990 [1923]), and those of emplotment and narrative identity formulated by Paul Ricoeur (I990, I99I). For Bakhtin, the self is necessarily constituted through its relation with an other. These two poles of self and other are ultimately two different ways of perceiving time and space, the former marked by its openness, the latter by its closedness. The Bakhtin scholar Holquist notes: 'For the perceivers, their time is forever open and unfinished; their own space is always the center of perception, the point around which things arrange themselves as a horizon whose meaning is determined by wherever they have their place in it. By contrast, the time in which we model others is perceived as closed and finished' (2002:22). The implication of this is that it is only from the time/space of the 'outside' that the person can come to be seen as a unique, consummated whole. The achieving of this consummation by the other is predicated on what Bakhtin calls 'transgredience': the ability to fully know the person as object and to thereby fix them in a particular time and space. The Amerindian perspectival cosmology outlined by Viveiros de Castro can be viewed as just such a struggle for transgredience (1998). But whereas the consummation of the dead Mapuche person ensures its autonomy; for the living, transgredience would be a reduction to the status of victim.

The value of this approach in revealing the function of the consummation of the Mapuche person realized in amulpïllïn is made evident when we review a famous passage by Bakhtin considering the 'hero' as deceased and the 'author' as wewpife:

ETHNOS, VOL. 72:I, MARCH 2007 (PP. 77-IOI) 
And this being outside in relation to the hero enables the author to collect and concentrate all of the hero, who, from within himself, is diffused and dispersed $[\ldots]$; to collect the hero and his life and to complete him to the point where he forms a whole by supplying all those moments which are inaccessible to the hero himself from within himself; [...] and to justify and to consummate the hero independently of the meaning, the achievements, the outcome and success of the hero's own forward directed life. (I990:I4).

While the concepts of transgredience and consummation may help us to understand the salience of the externality of the speaker in relation to the deceased, the notions of emplotment and narrative identity described by Paul Ricoeur highlight the way in which a narrative can stand mimetically for a life. For Ricoeur, human experience is characterized by narrative identity, that is to say, that the discordant and potentially infinite series of events which constitute each biological life are transformed through emplotment into a narrative identity which is unified, concordant, and finite (I99I:23). Emplotment, defined by Ricoeur as 'the synthesis of heterogeneous elements' (I99I: $2 \mathrm{I}$ ), is ultimately a dynamic process emerging through the constant interplay of discordance and concordance, openness and closure. The parallels with consummation are clear - both involve the creation of a coherent narrative from an infinitely disparate sequence of events. The main difference between the two is that Ricoeur's focus is on the creation of a self through narrative, whereas Bakhtin focuses on the creation of an other through narrative. As Ricoeur notes: 'We can become our own narrator $[\ldots]$ without being able to become the author' (I991:32). A synthesis of the insights of Bakhtin and Ricoeur leads to a dual emphasis on firstly, the necessary alterity of the author, and secondly, the condensation of a disparate life into a narrative. We can perhaps start to see why the story the living tell about the dead in amulpüllün is described by the Mapuche as a 'completion' or 'finishing.'

I have described above how Mapuche people conceptualize the life of a person, in a way echoed by Bakhtin and Ricoeur, as inevitably constituted through its open-ended relations with 'others.' These can be chronologically prior 'others' of paternal and maternal kin, or chronologically subsequent 'others' approached through exchange. The amulpüllün creates and presents a meaningful whole out of this life constituted through relations with others. It creates this 'whole' through condensing what is diffuse, an essence which corresponds to the uniqueness of an individual life. It is only this 'whole,' cut free of the relations from which it was constituted, that can move on from the realm of the living into the unknown and unspecified realm of the dead. 
It is only others who, from the necessary perspective of 'outsidedness,' are capable of achieving the transgredience necessary to consummate the person. Thus, as Bakhtin notes, 'Biography is bestowed as a gift' (I990[1923]:I66). However, this 'gift' is a very distinct kind of gift to that envisaged by Mauss (I990 [1925]), as the very nature of the 'gift' of amulpüllïn is to remove the recipient from the realm of sociality and thus remove the possibility of reciprocation. ${ }^{23}$

This creation of a whole from what is diffuse can simultaneously be described as the transformation of the deceased person from subject to object. In an account of amulpüllïn provided by Schindler, part of the discourse is addressed to the deceased themselves: 'You have already become an other' [Map. ka che] (I996:I68). Here, the werwpife place great emphasis on objectification as it is this change in epistemological status which serves to separate the deceased from the living. When we understand amulpüllün in terms of an othering achieved through objectification, parallels start to emerge with mortuary practices from elsewhere in South America which at first glance seem radically different. The Wari' funerary cannibalism described by Vilaça (2000) and Conklin (200I) is similarly the demarcation of the dead from the living through a process of objectification. Thus, for the Wari' the very act of eating is simultaneously an act of objectification and othering - the prey which one eats cannot by definition be one of 'us.'

The fact that the deceased is now cut free from the relations of reciprocity through which they constituted themselves is made clear in the mariepüll, the ritual toasting at the end of the amulpüllün. In stark contrast to the careful and meticulous etiquette usually observed when wine is exchanged, the drinkers in the mariepüll seize bottles and gulp down wine themselves before passing them on to anybody else. There is no concern with maintaining the anti-clockwise direction of the bottle, no concern with ensuring that all are served, no concern with thanking anybody: the bottles are dumped unceremoniously on the ground when empty. I suggest that just as the 'gift' of biography, the nutramtun, is by its very nature impossible to reciprocate, so too the mariepiull, which stands as the 'gift' of wine from the deceased, is also destined to never be returned. The whole point of the mariepuill is that it marks the end of reciprocity, and therefore the end of sociality.

We have seen that death is the cessation of sociality, but paradoxically it is a cessation which must be achieved by others. This is true in both the morally-negative causation of death by witchcraft, and in the morally-positive consummation of the deceased by the werwpife orators and friends. The

ETHNOS, VOL. 72:I, MARCH 2007 (PP. 77-IOI) 
fact that all deaths are caused by the ill-will of others, namely kalku witches, becomes especially salient in funerals as it is said to be at funerals that poisoned wine is most often given. One friend told me that the 'old-time people' liked to eat meat so much that when they had a funeral in their own lof, they would poison one of the guests in order to ensure that there would soon be a similar occasion for their hospitality to be returned in the guest lof. Reciprocal killings therefore ensured a constant cycle of reciprocal funeral feasts. Yet, just as the paradigmatic negative other in the form of the witch causes death; it is the paradigmatic positive other, in the form of the wewpife who enables death to be a consummation of the unique person and thereby secure their autonomy.

\section{Biography and the Amerindian Person}

In this paper I have focused on Mapuche funeral oratory as a form of synthesis, a condensation of the diffuse relationships of which the Mapuche person is composed. Such a view challenges the assumption that mortuary practices are necessarily equivalent to analysis, to disintegration, deconception, and division. Of course, these processes of division do occur when Mapuche people die: the body is separated from the alwe life essence, from the am soul, from the püllï spirit; and perhaps most emphatically, the deceased is separated from the community of the living. Yet, such processes of separation occur simultaneously with processes of unification. Indeed, it could be argued that separation is dependent upon unification as it is only the 'finished' person who can be sent away from the community of the living to the unspecified domain of the dead. A full description of a Mapuche funeral would therefore have to recognize processes of both analysis and synthesis, of both tearing apart and piecing together.

Such issues bear directly upon debates surrounding the nature of the Amerindian person which according to authors such as Taylor (I996), Viveiros de Castro (2002), and Vilaça (2005) is inherently unstable and dividual due to the necessary incorporation of the other into the subject. One implication of such a viewpoint would seem to be that the Amerindian person can never be conceived of as a 'whole' or be the object of totalization (Vilaça 2005:460). Like the Amerindian conceptions of the person described by the above writers, the Mapuche person is also constituted through internalized relations with others. Thus, during life the Mapuche person is in a dynamic state of centrifugal sociality. Yet, upon death this dynamism and open-endedness must be brought to an end through amulpüllïn, the purpose of which is to

ETHNOS, VOL. 72:I, MARCH 2007 (PP. 77-IOI) 
finish the deceased through totalization, to make them into a meaningful whole. This possibility of synthesis and totalization through biography raises the question of just how dividual the Amerindian person really is. Of course it could be argued that Mapuche people are simply anomalous in their practice of objectifying and totalizing the person, after all in terms of regional ethnography the Mapuche can be seen both as peripheral and obscure. Yet, there is evidence from throughout the Americas which suggests that representation of one's own person (autobiography) and of other persons (biography) as wholes is a practice widespread among Amerindian peoples. ${ }^{24}$

In Amazonia where the Amerindian person is apparently at its most 'chronically unstable,' we would perhaps expect a form of discourse which relies on objectification and totalization to be absent - but this is far from the case. As Basso has argued for the Kalapalo, biography is fundamental to society; it is the engine of ideological change as well as the root of the self (I989). In her recent work Suzanne Oakdale has described how autobiographical forms are central to Kayabi people in the Lower Xingu (2005). Political oratory, shamanic healing, and mortuary practices are all focused around autobiographical narratives. These narratives operate through the speaker's description of himself from the perspective of others through the use of extensive thirdperson quotation. Thus it is through narrative that the multiplicity of voices are subordinated and a degree of totalization is achieved: 'each narrator's body is a locus and animator of a variety of perspectives or voices. As such, each body provides a powerful image of how these perspectives can be brought into alignment' (2005:170).

It would be tempting to present the version of the Mapuche person I have presented here - that of a fixed, condensed, and unified individual - as a critique of those studies which have suggested that the Amerindian person is unstable, divisible, fleeting, and always at the mercy of the perspective of the other. Yet I do not believe that these two different views of the Amerindian person are necessarily contradictory. Indeed, I think it may well be that the former is a solution to the ontological problem posed by the latter: that the totalization of the person in biography is a response to the degree to which the person can be seen as unstable. In a world in which the person is defined by the perspective of the other, biography acts as a preemptive strike as it were: it determines, co-opts, and controls the perspective of the other and in doing so fixes, unifies, and stabilizes the person. If we choose to see sociality in the Americas as a battle for transgredience, a struggle for the subject position, we can start to understand the importance of being objectified by friends

ETHNOS, VOL. 72:I, MARCH 2007 (PP. 77-IOI) 
rather than enemies. In such a light Bakhtin's comment gains new relevance: biography truly is a gift.

\section{Acknowledgments}

This article is based upon 23 months of fieldwork carried out from September 200 I to August 2003 in the rural communities of Piedra Alta and Isla Huapi located between Lago Budi and the Pacific in Chile's Ninth Region. The fieldwork was funded by the Economic and Social Research Council, the Sutasoma Prize administered by the Royal Anthropological Institute, and the Central Research Fund of the University of London. The article was written under a British Academy Post-doctoral Fellowship. I am grateful to all of these organizations for their support. I would also like to thank Rita Astuti, Maurice Bloch, Philippe Descola, Peter Gow, Olivia Harris, Maya Mayblin, Suzanne Oakdale, Helmut Schindler, Michael Scott, and three anonymous reviewers for Ethnos, for their productive comments on previous versions of this article. Further insights came from participants in the ISCA/Linacre Amazonia Seminar at the University of Oxford, and the CIASE Seminar at the University of St Andrews. I am especially grateful to the many people in Piedra Alta and Isla Huapi with whom I discussed amulpüllïn. In particular, María Antileo Quimen, Roberto Millao Chequecoy, Sergio Painemilla Huarapil, and Raúl Painemilla Painemilla went out of their way to explore these issues with me.

\section{Notes}

I. Following Harris, I take the 'person' to refer to a publicly acknowledged 'agentin-society' (1989:602), while I take 'individual' to refer to 'a single member of the human kind' (I989:600).

2. See Conklin 200I for an exception to this general trend.

3. See Rival 2005 for a similar point regarding the nature of the Amazonian 'soul.'

4. The Mapuche are an indigenous group numbering approximately one million people in Chile with a further 40,00o on the Argentinean side of the Cordillera. Most Mapuche people in the rural south are bilingual in Spanish and the Mapuche language, Mapudungun. Around half of the Chilean Mapuche have migrated to the urban centres over the past decades.

5. There is much debate and little consensus over the meaning of these terms, both among contemporary Mapuche people and their ethnographers. What seems clear, however, is that none of these concepts is equated directly with social relationships, they appear rather as pseudo-physiological aspects of the living person. See Course 2005 for a discussion of the interrelation between alwe, am, and püllii.

6. In other Mapuche areas, the term used is küpalme.

7. Although the reservation system was abolished many years previously, people still spoke of their communities as reducciones 'reservations.'

8. See Course 2005 for a fuller description of Mapuche social relations.

9. Those who are temporarily incapable of engaging in the sociality of friendship, such as newborn babies or drunk people, are denied the status of true persons and thus referred to as chenglay 'not persons.'

Io. Although my use of Bakhtin in this essay is confined to his earlier work, the Mapuche conceptualization of the person as composed of a multiplicity of styles (or even genres) of relating to others, could clearly be analysed in terms of the dialogism

ETHNOS, VOL. 72:I, MARCH 2007 (PP. 77-IOI) 
most explicitly expressed in his later work. See Lipset 1997 for an example of a dialogical approach to culture.

II. Although the suffix em usually refers exclusively to dead people, it may also be used to refer to anyone who has disappeared or left the area never to be seen again (hence its use in songs of lost love).

I2. Wampo is actually a loan word from Quechua; the Mapuche word for canoe, trolof, is no longer used.

I3. Sources for earlier accounts of Mapuche funerals include Coña I930; Guevara I9o8, I925; and Latcham I924.

I4. The etymology of umatun is unclear; perhaps from umaztun 'to sleep.' Faron gives the Mapuche term for wake as kurikazwin 'black party' (I963:I37).

I5. Up until the mid-twentieth century, a che mamüll would also be placed alongside the cross at the head of the coffin. The che mamüll 'person of wood' was a large anthropomorphic statue carved in wood. A knife would sometimes be buried in its side to show that the deceased person it represented had been malofe, a war raider (see Coña I930).

I6. Those guests who are 'invited' are the close kin of the deceased who belong to a distinct lof; a man's matrilateral kin, and a woman's patrilateral and matrilateral kin. However, as mentioned above, many of these 'guests' now choose to act as 'hosts.'

17. Whereas in the ngillatun fertility ritual, azwun are always carried out on horseback at a full gallop; in eluzoün, the awun tend to be carried out on foot.

I8. I thank Michael Scott for bringing my attention to this point.

I9. See Schindler I996 for a description of amulpüllün held in a Mapuche community in the Cordillera.

20. Schindler notes in his account of amulpüllün that kin are explicitly prohibited from serving as wewpife (1997). This has parallels with the mortuary rites described by Conklin (200I) and Vilaça (2000) for the Wari' in which it is up to the affines of the deceased to carry out the rites and thereby demonstrate the reality of the death to the deceased's consanguineal kin.

2I. Ricoeur writes: 'gathering factors into a single story makes the plot a totality which can be said to be at once concordant and discordant (this is why I shall speak of discordant concordance or of concordant discordance)' (I99I:2I).

22. The Capuchin lexicographer Felix José de Augusta translates derwman into Spanish as dejar concluido 'to leave finished' (I996 [I9I6]:30).

23. See Parry I 986 for a discussion of the gift which must not be reciprocated.

24. Indeed, the nature of Amerindian autobiography is the one of the most debated topics among students of Native North America. While writers such as Krupat (I996) have argued that native autobiography has resulted primarily from the imposition of a western literary form, others such as Wong (I992) have argued convincingly that the representation of it is an indigenous process which has pre-Columbian roots.

\section{References}

Augusta, Felix José. r99r [r916]. Diccionario Araucano. Temuco: Editorial Kushe. Bakhtin, Mikhail. I990 [I923]. Art and Answerability: Early Philosophical Essays (trans. V. Liapunov). Austin: University of Texas Press.

Basso, Ellen. I989. Kalapalo Biography: Psychology and Language in a South American Oral History. American Anthropologist, 9I (3):55 I-569. 
Bloch, Maurice. I988. Death and the Concept of the Person. In On the Meaning of Death, edited by S. Cederroth \& C. Corlin \& J. Lindström. Acta Universitatis Upsaliensis. Uppsala Studies in Cultural Anthropology, 8.

Carneiro da Cunha, Manuela. I978. Os mortos e os outros: Uma analisis do sistema funerario $e$ da noção de pessoa entre os indios Kraho. São Paulo: Hucitec.

Coña, Pascual. r984 [1930]. Testimonio de un Cacique Mapuche. Santiago: Pehuen.

Conklin, Beth. 20or. Consuming Grief: Compassionate Cannibalism in an Amazonian Society. Austin: University of Texas Press.

Course, Magnus. 2005. Mapuche Person, Mapuche People: Individual and Society in Indigenous Southern Chile. Unpublished PhD Thesis, University of London.

Damon, Frederick \& Roy Wagner (eds). I989. Death Rituals and Life in the Societies of the Kula Ring. DeKalb: Northern Illinois University Press.

Faron, Louis. I96r. Mapuche Social Structure: Reintegration in a Patrilineal Society of Southern Chile. Urbana: University of Illinois.

- I963. Death and Fertility Rites of the Mapuche (Araucanian) Indians of Central Chile. Ethnology, 2:I35-I 56.

Guevara, Tomás. 1908. Psicología del pueblo araucano. Santiago: Imprenta Cervantes.

-. I925. Historia de Chile: Chile prehispano. Santiago: Belcells \& Co.

Harris, Grace. I989. Concepts of Individual, Self, and Person in Description and Analysis. American Anthropologist, 9I(3):599-6I2.

Hertz, Robert. I960 [1907]. A Contribution to the Study of the Collective Representation of Death (trans. R. \& C. Needham). In Death and the Right Hand. London: Cohen and West.

Holquist, Michael. 2002. Dialogism: Bakhtin and His World. London: Routledge.

Kelly Luciani, José. 200I. Fractalidade e Troca de Perspectivas. Mana, 7(2):95-I 22.

Krupat, Arnold (ed.). I996. Native American Autobiography: An Anthology. Madison: University of Wisconsin Press.

Latcham, Ricardo. I924. La organización social y las creencias religiosas de los antiguos araucanos. Santiago: Imprenta Cervantes.

Lipset, David. I997. Mangrove Man: Dialogics of Culture in the Sepik Estuary. Cambridge: Cambridge University Press.

Macintyre, Martha. I989. The Triumph of the Susu: Mortuary Exchanges on Tubetube. In Death Rituals and Life in the Societies of the Kula Ring, edited by F. Damon \& R. Wagner. DeKalb: Northern Illinois University Press.

Mauss, Marcel. 1990 [1925]. The Gift: The Form and Reason for Exchange in Archaic Societies (trans. W.D. Halls). New York: W.W. Norton \& Co.

Mosko, Mark. I983. Conception and Deconception in Mekeo Culture. Mankind, Special Issue edited by D. Jorgensen.

Oakdale, Suzanne. 2005. I Foresee My Life: The Ritual Performance of Autobiography in an Amazonian Community. Lincoln: University of Nebraska Press.

Oxford English Dictionary. 1989 (2nd ed.). Oxford: Oxford University Press.

Overing, Joanna 1993. Death and the Loss of Civilized Predation among the Piaroa of the Orinoco Basin. L'Homme, 33(I26-I28):I9I-2I I.

Parry, Jonathan. I986. The Gift, the Indian Gift and the 'Indian Gift'. Man, 2 I(3): $453-473$.

Perrin, Michel. 1987. The Way of the Dead Indians: Guajiro Myths and Symbols. Austin: University of Texas Press. 
Ricoeur, Paul. I990. Time and Narrative Vol. 3 (trans. K. Blamey \& D. Pellauer). Chicago: University of Chicago Press.

-. I99I. Life in Quest of Narrative. In On Paul Ricoeur: Narrative and Interpretation, edited by David Wood. London: Routledge.

Rival, Laura. 2005. The Attachment of the Soul to the Body Among the Huaorani of Amazonian Ecudaor. Ethnos, 70(3):285-3ro.

Schindler, Helmut. I996. Amulpüllün: Un rito funerario de los mapuches chilenos. Lengua y literature mapuche, 7:165-180.

Strathern, Marilyn. I988. The Gender of the Gift: Problems with Women and Problems with Society in Melanesia. Berkeley: University of California Press.

-. I992. Parts and Wholes: Refiguring Relationships in a Postplural World. In Conceptualising Society, edited by Adam Kuper. London: Routledge.

Stuchlik, Milan. I976. Life on a Half Share: Mechanisms of Social Recruitment among the Mapuche of Southern Chile. New York: St. Martin's Press.

Taylor, Anne Christine. 1996. The Soul's Body and its States: An Amazonian Perspective on the Nature of Being Human. Journal of the Royal Anthropological Institiute, 2(2):2OI-2I5.

- I998. Corps immortels, devoir d'oubli: formes humaines et trajectoires de vie chez les Achuar. In La production du corps: approches anthropologiques et historiques, edited by M. Godelier \& M. Panoff. Amsterdam: Éditions des Archives Contemporaines.

Vilaça, Aparecida. 2000. Relations Between Funerary Cannibalism and Warfare Cannibalism: The Question of Predation. Ethnos, 65(r):83-106/

- 2005. Chronically Unstable Bodies: Reflections on Amazonian Corporalities. Journal of the Royal Anthropological Institute, II (3):445-464.

Viveiros de Castro, Eduardo. I992. From the Enemy's Point of Viez: Humanity and Divinity in an Amazonian Society. Chicago: University of Chicago Press.

-. I998. Cosmological Deixis and Amerindian Perspectivism. Journal of the Royal Anthropological Institute, 4(3):469-488.

- 2002. GUT Feelings about Amazonia: Potential Affinity and the Construction of Sociality. In Beyond the Visible and the Material, edited by Laura Rival \& Neil Whitehead. Oxford: Oxford University Press.

Wong, Hertha. 1992. Sending My Heart Back Across the Years: Tradition and Innovation in Native American Autobiography. New York: Oxford University Press. 